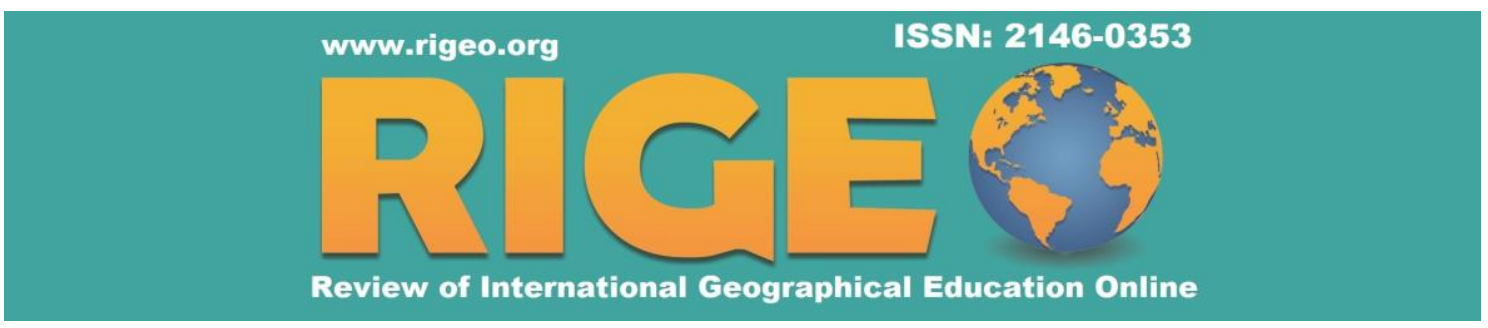

To cite this article: Krohmer, M.; Budke, A. (2018). Understanding and Assessment of Innovation by Geography Teachers in North Rhine-Westphalia: A German Case Study. Review of International Geographical Education Online (RIGEO), 8(3), 415439. Retrieved from http://www.rigeo.org/vol8no3/Number3winter/RIGEO-V8-N3-1.pdf

\title{
Understanding and Assessment of Innovation by Geography Teachers in North Rhine- Westphalia: A German Case Study*
}

\author{
Maxim KROHMER ${ }^{1}$ \\ University of Cologne, Cologne, GERMANY \\ Alexandra BUDKE ${ }^{2}$ \\ University of Cologne, Cologne, GERMANY
}

\begin{abstract}
Innovation is an integral part of much of today's society, including geography teaching. Geography education has the potential to develop through innovative approaches to the formation of methods and content in the classroom. The concept of innovation is much discussed, but there has been minimal research into teachers' actual understanding of innovation. The aim of the following study is to determine the understanding of innovation by geography teachers, and specifically to identify understanding and assessment patterns that lead to certain intentions for acting with innovation. First, a theoretical framework is developed in the form of an innovation matrix, which allows innovation to be divided into different classes, levels of impact and with corresponding actors in geography lessons. Subsequently, ten geography teachers were asked in an empirical study in narrative interviews about their understanding and assessment of innovations. The results of this study showed different patterns of understanding and assessment of innovation, perceived innovative methods, media and content in class and obstacles to the implementation of innovation.
\end{abstract}

\section{Keywords}

Social Innovation; Innovation Research; Geography Education Research; Qualitative Research; Teacher Perception

\footnotetext{
*This article is a part of a doctoral thesis and is the first out of three articles.

${ }^{1}$ Corresponding author: PhD candidate, Institute for Geography Education, University of Cologe, Gronewaldstr. 250931 Cologne Germany, e-mail: mkrohmer[at]uni-bonn.de +49228 733527

${ }^{2}$ Prof.; Institute for Geography Education, University of Cologne, Gronewaldstr. 250931 Cologne Germany, e-mail: alexandra.budke[at]uni-koeln.de +49 221/ 4701895
} 
Today's society has reached an accelerated state of change and susbsequently constant adaptation to new conditions is a continuously occurring phenomenon. Globalization, digitalization and demographic change are some of the driving forces of these changes. In this regard, every sector of society, be it industry or trade, politics, research or education, is involved in the ubiquitous "pressure to innovate" (Gryl, 2013, p. 16). Openness to reforms and paradigm shifts are key elements to successfully accomplish this. While research into innovation has traditionally attached value towards technology, social innovations have also been studied over the last decade in the context of educational science (Bormann, 2013, p. 90). Schools are constantly confronted with different kinds of innovations such as changes in the curriculum, foster inclusion and diversity, or simply the constant flow of new methods and technological tools to be incorporated into teaching, all of which are intended to improve teaching and learning.

So, what does such innovation mean for geographical education? Geographical teaching seeks to empower learners with a life-long understanding of the world around them, with the aim of actively shape their lives and enabling them to participate in the society in a diverse and successful way (Lambert 2011; Lambert, Solem \& Tani 2015). Research into geography education aims to provide the educational foundation for this endeavor, like in the sense of the 'Geo-Capabilities' approach, where the focus is on everyday life situations and subject-specific concepts and methods only serve to shape and cope with them (Jeckel \& Pichler 2017). But it is still unclear how teachers perceive innovations and interact with innovations in teaching geography. Uncertainties with respect to new theories and methods such as spatial citizenship or geographical argumentation, top-down introductions, such as changes in the curriculum, and a constant time pressure, can create a skeptical attitude towards innovation in the classroom (Schulze, et al. 2015; Budke \& Uhlenwinkel, 2011). Despite many studies being undertaken on successful innovation cultures (Lauer, 2006; Reimann-Rothmeier, 2003) and the implementation of innovation in schools (Radtke, 2004; Gräsel \& Parchmann, 2004; Goldenbaum, 2013), limited attention has been paid to how teachers understand innovation and how it influences their professional actions. This is surprising as teachers and their teaching practices influence the teaching and learning success of students to a great extent. Consequently, the main thrust of this study is to investigate the understanding and assessment patterns of geography teachers in relation to innovation, by identifying individual perception criteria of innovation and tendencies that affect the assessment of innovation in teaching geography.

The research questions considered here are:

- What is the understanding of innovation by geography teachers?

- What does innovation in geography lessons depend on?

- To what extent does the understanding of innovation by geography teachers influence their assessment and intention to realize innovations in geography lessons?

First, the theoretical background of the study and the term innovation, as well as its significance for geography education, is illustrated. Secondly, the methodical procedure 
of the study will be explained and then the research findings will be presented and interpreted. Finally, the results will be related to the research questions and their consequences for further research will be discussed. The results of this study serve as a prerequisite for a planned teacher training with the aim to sensitize teachers with the handling of school innovations and to present the conditions and obstacles for school innovations in geography. Moreover, the results presented here can be used to develop more focused new innovative approaches based on the needs of teachers.

\section{Theoretical Framework}

\section{The Definitions of Innovation}

In common understanding, the term 'innovation' is associated with fundamental changes, inventions and improvements. In layman's terms, an innovation contains something new. Although the term can be derived from the Latin 'innovatio' (something newly created), there is no universal definition of the term innovation in science literature (Reinmann-Rothmeier, 2003, p. 8). Hence, a more detailed explanation of the term is required to go beyond the basic understanding of the term.

Formerly innovation was linked to radical-revolutionary changes that were considered to have short-term and drastic effects, developed by individual ideas by a limited number of specialists (Bullinger, 1994). An example of such an innovation is the invention of the telephone and its establishment as a main tool of communication. In a more recent understanding, innovation shows a more evolutionary, incremental character. Examples of this evolutionary understanding range from the continuous improvement of smartphones to the long-standing development of an education system through curricula and standards, to the establishment of new leadership styles that can impact organizational features. For such examples like these the impact of an innovation may be less obvious. The modern understanding of innovation is that anyone can be a source for ideas on innovation (without being an expert) and "[...] that group work and team spirit are more likely to succeed than solitary thinking and elbow mentality" (Reinmann-Rothmeier, 2003, p. 11). To read more about these concepts of radical and incremental innovation see in Ettlie et al. (1984), Dewar \& Dutton (1986) and Arnold et al. (2010).

\section{Innovation in Educational Research}

In 1912, Schumpeter, as part of his Theory of Economic Development, designed the notion of innovation as a term for a process by which new products and technologies are introduced into an economic system. However, it was not until the 1960s that the term 'innovation' was used in German pedagogical discussion to convert the 'technological innovation' to 'social innovation'. Social innovations are by definition, processes of creation, implementation, and dissemination of new social practices in different areas of society (Zapf 1989, p. 170). Subsequently, the term was quickly spread and replaced similar terms such as novelty, reform, or educational experiment (Schramm, 2007, p. 12). Within the innovation research of educational science, several different meanings of the term innovation exist. In this respect, Rürup \& Bormann (2013) propose a summarizing heuristic of the different meanings of the concept of innovation. In short, 
they differentiate the term innovation into innovation as a concrete idea or as the result of a social transformation process (content), innovation as a process of creation and dissemination of novelties in social systems (process) and innovativeness as the ability to innovate (potential) (see Table 1).

Table 1

Different Meanings of Innovation (Rürup \& Bormann, 2013, p. 19)

\begin{tabular}{c|l}
\hline a) Content & \multicolumn{1}{|c}{ descriptively analytic } \\
\hline b) Process & $\begin{array}{l}\text { Innovation as an idea, practice, object, } \\
\text { occasion; the result of a process. }\end{array}$ \\
\hline c) Potential & $\begin{array}{l}\text { Change as a constant process of alteration } \\
\text { taking place in a social context } \\
\text { To innovate with a purpose induced by social } \\
\text { development }\end{array}$ \\
\hline
\end{tabular}

In basic terms innovation refers to something 'new', which is more than just a rudimentary improvement. Most definitions show that inventions, as the pure idea of something new, can not necessarily be seen as innovation. "Only the implementation, usage, and associated visible changes of the initial state make an innovation out of an invention" (Schmid, 1999, p. 103). The decision to innovate is to be distinguished to the actual implementation, such as the difference between a teacher's decisions to use a new method to its subsequent application in a classroom setting. This decision phase is referred to as adoption (Fullan \& Pomfret, 1997, p. 336; Klein \& Knight, 2005, p. 243).

While the decision to innovate is an important and necessary step, it sometimes has relatively small relevance to its actual application. The implementation phase goes beyond the decision for innovation. It begins with the realization of innovation in practice and ends as a tool for standard practice. According to this understanding, the implementation is only completed, when the innovation is generally used in situations provided for it (e.g. a school lesson).

This difference between adoption and implementation is significant: "Individuals, teams, organizations, and communities often adopt innovations but fail to implement them successfully" (Klein \& Knight, 2005, p. 243). Hence, the implementation of innovations can be understood as "the critical gateway between the decision to adopt the innovation and the routine use of the innovation" (Klein \& Knight, 2005, p. 243).

For better understanding and utilization of the term innovation in an educational context, it is necessary to develop the definition further. Schaub and Zenke (2007) proposed a basic classification for school-related innovations, in which they grouped innovation in curricular, institutional and methodical innovations (Table 2). 
Table 2

Classification of School-Related Innovations (Schaub \& Zenke, 2007, p. 306)

\begin{tabular}{ll}
\hline School-related innovations & \multicolumn{1}{c}{ Meaning } \\
\hline Curricular innovation & Systematization of topics in school subjects \\
& Emphasis and progression of topics in a \\
& school subject \\
\hline Institutional innovation & Determination of learning objects, classes, \\
& learning places \\
& Employment \\
& Financing \\
& Cooperation agreements \\
\hline Methodical innovation & Arrangement of the class subject \\
& The use of media and technology in the \\
& subject \\
& Distribution of roles in class situations \\
& Evaluation methods and evaluation forms \\
\hline
\end{tabular}

In addition to this basic and objective classification, innovation in schools are also found in the context of new, targeted, intended and planned measures that can bring changes or improvements on a number of different levels. Changes can affect the school education system (macro-level), the individual school (meso-level) and/or the school lessons themselves (micro-level) (Goldenbaum, 2013, p. 151). Consequently, these different levels of innovation are not absolute but rather relative, based on objective or subjective criteria of different actors within their according level of effect. Innovations in a school context have a less radical character of change, but rather an evolutionary, gradual constructive character (Reimann, 2005, p. 14).

\section{Innovation in Geographical Education}

Geography education research critically examines geography and its potential for geographic and general education. Development and research activities in geography education research either relate to applied or basic research (Budke, 2015, p. 11). For example, geography education researchers develop theoretical concepts for education to enable sustainable development of new curricula (Böhn \& Hamann, 2011; Birkenhauer, 2002). Research in this field also aims to develop effective use of new digital media in geography lessons and concepts are suggested that help students in the development of systemic thinking (Höhnle, et al., 2013; Jahn et al., 2015).

Figure 1 summarizes the previous theoretical approaches with reference to a geographic context. The matrix is divided into three main columns and a fourth column for support with examples. The column 'Classification' first indicates the respective type of innovation, e.g. 'methodical innovation' includes innovative methods and media. The column titled 'Level' describes the level at which innovation has an effect, i.e. innovation influences the 'macro-level' (school system), the 'meso-level' (school) or the 'micro-level' (school lesson). Finally, the column 'Actor(s)' describes the actors who are responsible for the respective innovation in relation to the corresponding level, e.g. the teacher as the initiator of methodical innovation in the classroom (micro-level). For example, an innovation from the field of digitalization research can be seen as a 
methodical innovation on a micro-level, in form of the usage of new digital map material in geography class. The main actors for the implementation of this innovation are geography teachers and students. Another example is the organization of out-ofschool-laboratories as an institutional innovation on a meso-level, which is utilized by the principal and respective geography teachers in a school. A macro-level innovation would be the change from an input-oriented to an output-oriented geographical education, in which the main actors are the education researchers or the educational policymakers.

Figure 1. Innovation matrix with highlighted focus on teachers for this study (own illustration).

The classification of innovation types and their relation to a particular level is not absolute. Borders between each innovation class (curricular/methodical/institutional) should not be seen as absolute as some types of innovation cannot be clearly allocated

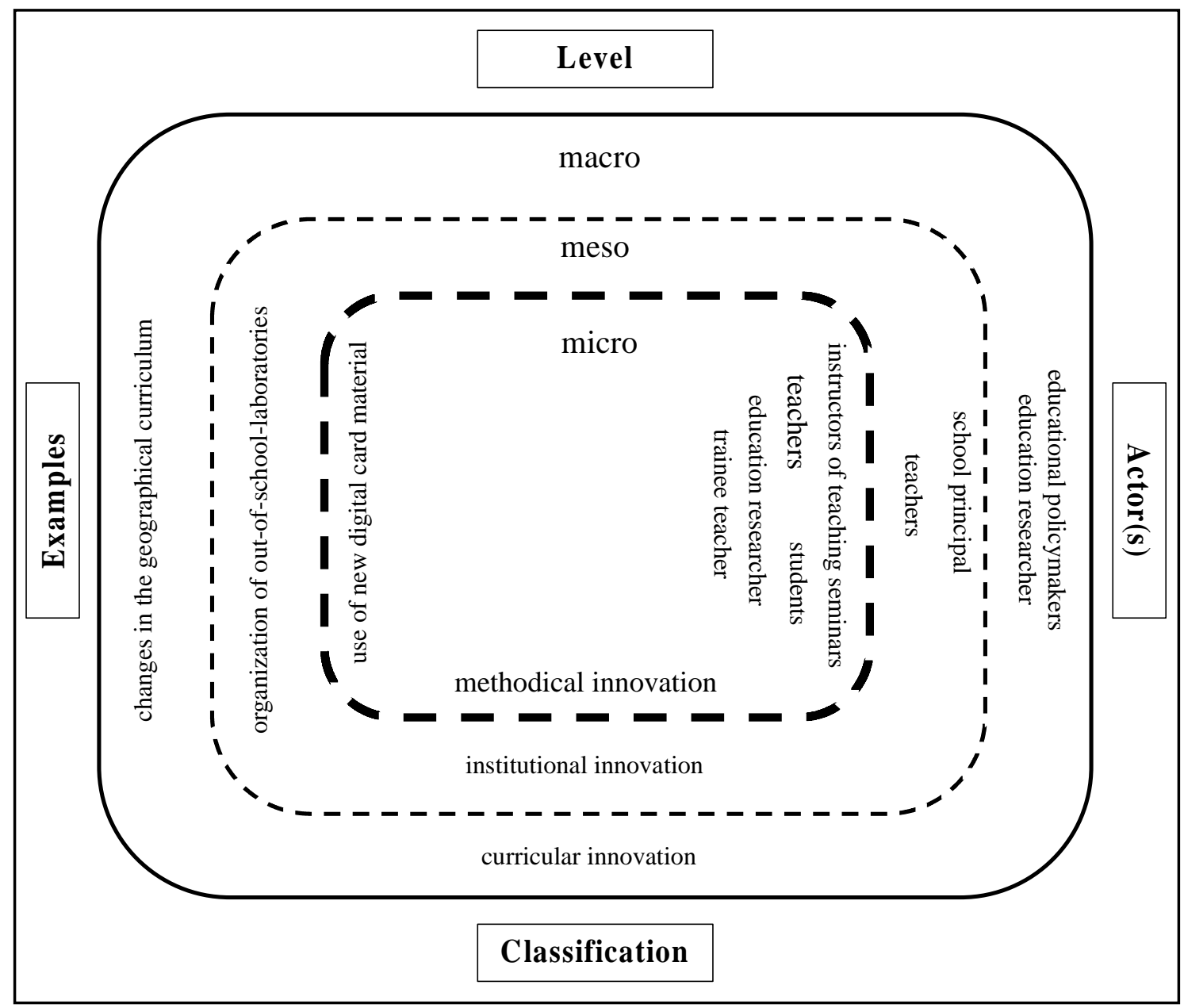

to a specific level. Innovations at the meso-level do not always have to be institutional innovations. For example, the introduction of a new school book in geography for the whole school can be assigned to an innovation on a meso-level but can be related to a methodical innovation, because of the use of new media for the class subject (see Table 2). 
As already mentioned, teachers are among the key actors in influencing the learning success of students (Helmke, 2012, p. 109). Moreover, studies also show that teachers play a central role in the process of implementing reforms and for innovation in a school context (Borko, 2004; Döbert et al., 2003). Considering this and the research questions previously outlined, the focus of this study is on the micro-level, specifically considering methodical and medial innovations with teachers as the key actors. For this purpose, our definition of innovation in geography teaching for the micro-level is:

Innovations in geography classes are deemed to be alterations that lead to a break with routines and are accepted and recognized by the respective social environment (teachers, students). The changes can consist of new combinations of known elements and thematic contexts and do not have to be fundamentally new. They should be repeatable as well as convertible into new routines.

In our understanding, innovation in geography classes can be manifested in new social contents, processes, and potentials (see table 1), which deviate from regular procedures; for example, the introduction of a new method or teaching procedure. It does not matter who the source of innovation is and can range from a scientific innovation to a student idea put into practice. This novelty must be accepted by the actors in which it is active; students and the teacher must recognize the value of the novelty. To distinguish this kind of social innovation from a purely random event, the innovation must be repeatable. The completion of the innovation is achieved when it has been turned into a new routine (Reinmann-Rothmeier, 2003, p. 9.).

\section{Methods}

In the following segment, the research methods used for this project will be presented. For clarity, qualitative data collection and data evaluation procedures are explained in addition to the theoretical and organizational background of the research process. Furthermore, the constraints of the methods used and how these were addressed are reviewed.

\section{Research Design}

The research questions outlined in the introduction have not been empirically investigated in the context of geography education research previously, which leads this study to have a strong explorative nature (Mayring, 2002). The study aims to demonstrate the understanding of innovation by geography teachers in relation to their activities in the classroom and seeks to identify the individual experiences of the teachers, including how they developed their understanding of innovation and their assessment and interaction with innovation. Thus, this study aims to understand the thought patterns and subjective theories (Mandl \& Huber, 1982; Dann, 1994) of innovation and how they influence perception, judgment, and handling of innovation by geography teachers.

\section{Data Collection and Data processing}

A research design that allows interviewees to openly describe their experiences from everyday school life in detail was needed to survey the subjective experiences and 
assessment patterns of geography teachers. Consequently, a narrative interview approach (Schütze, 1983) was used, as it focuses on a "specific, temporal and thematic excerpt" (Flick, 2011a, p. 228) from the respondent's life. Moreover, it encourages the interviewee to "tell the story of the subject matter in question as a coherent history of all relevant events from beginning to end" (Hermanns, 1995, p. 183). In this approach, the interviewee was asked to tell a narrative of a process-related act, that they had experienced (such as an ordinary lesson) without interruption of the narrative by asking further questions. After the interviewee finished their narrative immanent and exmanent questions were asked to address aspects of their narrative that were unclear. However, "narrative-episodic knowledge" generated in this way (Flick, 2011b, p. 273) was not sufficient to address all the research aims of this study. Hence, this study also investigated the subjective conception and evaluation of innovation in geography lessons, as well as a number of individual applications. For that purpose, the prepared exmanent questions were accorded greater importance. Using this method it was possible to ask important questions in each of the interviews, which made the interviews comparable. This methodological approach is comparable to the problem-centered interview, which aims to capture subjective perceptions and modes of processing social reality (Witzel, 1985). The interviewees were asked to describe their daily professional routines, for example, their usual teaching phases. In the subsequent immanent and exmanent question phase the focus was placed on how the interviewees break with routines in order to facilitate changes, specifically innovation, and the understanding of innovation. Through this approach the subjective understanding and assessment patterns of innovation in geography lessons were reconstructed, experiences with innovation were recorded, and their intentions with innovation in the classroom were compared.

Overall, ten interviews with geography teachers were undertaken for the exploratory study. Five men and five women were interviewed, whom all teach at different schools (but always at German Gymnasiums in North Rhine-Westphalia) and have different teaching experiences ranging from 1 to 36 years of active apprenticeship in schools. The reason for this selection was for theoretical sampling (Glaser \& Strauss, 1999) with the aim of identifying the largest possible differences. Intermediate results from the data analysis were used as impulses for further, refined data collection, e.g. the age of the teachers and their understanding and handling of innovation. This chosen sample was not representative in terms of socio-demographic characteristics or in relation to the whole teaching staff, nor to the group of geography teachers interviewed. The aim of this qualitative study was to identify a wide range of possible teacher perceptions and as different concepts as possible, and this goal guided the choice of interviewees.

\section{Data Evaluation and Data Display}

The analysis of the interviews was carried out according to the narrative method of Schütze (1983, Hermanns, 1992). Following Rosenthal (1987, p. 147) and FischerRosenthal/Rosenthal (1997, p. 153) narrative segments were considered in the interpretation as well as interpretation of the pure descriptions and arguments not embedded in narrations with regard to their connection to the narrative parts of the text. The method used was primarily focused on the procedure outlined by Schütze (1983). However, further methods were included in the evaluation. All interviews were also 
based on the coding method of Grounded Theory (Glaser \& Strauss, 1967); core and subcategories were identified in the material and linked with each other to form a network of constructs. Based on this, a classification of geography teachers was identified from the data material to address the research questions of this study. The interpretations were based on the main narrations, complemented by the exmanent demands.

The sampling structure of this study influenced the process of data analysis. It allowed the data collection and analysis to be linked through theoretical sampling (Glaser \& Strauss, 1999) so that intermediate results from the data analysis could be used as impulses for further, more refined data collection. The collected data was deemed appropriate, after an initial analysis, to allow to work on the research questions in depth. A further survey phase in the field was therefore unnecessary, even if it cannot be entirely ruled out that the extraction and evaluation of additional data, in the sense of theoretical saturation, would not have yielded further insights.

Development of the category system. Deductive and inductive approaches were combined for the category system of this study (Mayring, 2008). The deductive categories were derived from the theoretical and literal framework on the understanding of innovation (see the chapter 'Theoretical Framework'). This resulted in a category pattern, which was more distinguished and complemented during an inductive category formation after the interviews. Based on the inductive approach, a series of main categories were formed, which influenced both understanding of innovation and behavior patterns in geography education. The development of the category system and the classification underwent several modifications. After the theory-based survey and the inductive supplementation of the category system, after completing three interviews as a pretest, the category system was repeatedly refined and changed. A review of the category system by third parties (peers) served to ensure an intercoder reactivity, as is demanded by Mayring (2008). The relevant interview passages from the entire data material were assigned to the corresponding categories using MAXQDA.

\section{Methodical Challenges}

Narrative interviews are regarded as unsuccessful if the interviewee attempts to control their representations, for example, if they spoke along an already existing "narrative overlay" or the interview consists of a back-and-forth between the two actors with no or little narration (Küsters 2006, p. 67). This second problem happened during the pre-test phase as the narrative impulse was inappropriate for a longer narration by the interviewee. This problem was solved with the help of three further test in which the narrative impulse was refined, and consequently, the subsequent interviews contained enough narrations. Furthermore, innovation is a very complex topic that makes it difficult for teachers to talk about. Teachers found it difficult to talk about innovation in an everyday school context as an innovation can be a small change that quickly changes into a routine. Therefore, a more precise question about the understanding of innovation in school was asked in the exmanent question phase, after the main narration. Another problem was that the teachers did not like to talk about failures with innovation, so it was difficult to identify barriers that influence the realization of innovation in class. 
Again, a more precise question about constraints with the realization of innovations in school was asked after the main narration of the interviewee, to solve this problem. Another problem was that the interviews were conducted in German. The translation of individual interview passages in the evaluation section cannot reproduce the true notation and nuances of meaning. Therefore, important words for the evaluation have been partly left in German and are subsequently explained in their meaning. To ensure the anonymity of the teachers interviewed no full names are mentioned in the following part, only the respective abbreviations Mr. and Ms. as well as a random letter.

\section{Findings and Results}

\section{Understanding of Innovations}

A clear understanding of innovation by geography teachers could not be determined. However, a common denominator that everyone who was interviewed expressed was that innovation is something new, such as was expressed by Mr. F.: "Everything that is new, that is different in principle from what has been done so far, is innovative. That's what I understand" (personal communication, March 1, 2018). The teachers interviewed had very different ideas of these novelties and a basic distinction was made between two directions of understanding: curricular and methodical-medial. Subsequently, the teachers differentiated between innovation from outside (curricular innovations) and inside (methodical-medial innovations).

Some of the teachers interviewed understood curricular changes as innovation, such as the change from a 12-year to a 13-year school graduation (called G8 and G9), which affects the teachers interviewed from North Rhine-Westphalia, and was widely discussed: "The last major innovation the school has experienced was the educational reform and focus on competencies. From outside, school is influenced by innovation, for example, NRW is going back to G9" (Ms. H., personal communication, November 2, 2017). According to this understanding, schools experience major innovation through educational policy influences, which cannot be controlled by the teachers. Here, education policy is understood as an innovative control that affects teachers and forces them to react. These changes in education policy are associated with changes from "outside" and are partly seen as problematic.

According to Mr. R. (personal communication, November 3, 2017): "innovation from inside the teacher staff [...] is what represents an innovation." From "inside" the interviewed teacher understood innovations that concern methods and media that they are using in their own class. With "inside" they mean the personal area of influence of the teachers and their room for maneuver. Furthermore, we determined that teachers understood not only some geography education methods but also general education methods as innovative methods for their geography lessons. These innovations from inside they assessed very positively. Here they didn't distinguish between general educational innovations and geography education innovations. Based on the innovation matrix already presented, it is noticeable that the interviewed teachers made no reference to institutional innovations. Innovation that had an effect at the meso-level are either not noticed or have no significance for the teachers interviewed. Furthermore, 
innovation coming from geography education or geosciences are not considered as such. It can be assumed that the inner innovations are perceived as an innovation of their own and not as such which they adopt and implement from the outside (e.g. from the results of geography education research).

\section{Assessment of Innovation}

In addition to the presented patterns of understanding, the assessment of innovation took on a major role in the perception of the interviewed geography teachers. When teachers talked about their personal innovation in the classroom, they mostly put forward positive experiences. Mr. W. (personal communication, March 1, 2018) gave an example of this:

I did a treasure hunt in fifth grade once [...] like a diamond hunt. [...] They had a lot of fun (Megaspaß) and that's another positive conclusion. And why not use those ten seconds? And that's what I think the cool lessons are like.

It must be pointed out here, that not only personal performance is perceived as "cool", but that the fun of the students also played a central role in the own assessment and motivation with innovations. Herein the overarching context in which innovation takes place becomes apparent. Innovations and their impact are linked to the learning group, the teacher colleagues or the origin of the innovations. Ms. H (personal communication, November 2, 2017) saw also the students as an important factor for innovation:

[...] that means now I as a teacher have the opportunity to say in consultation with my students that this class offers the following [...] and I believe that these small kinds of innovation that can also be created [...], any teaching that is tailored to the actual group of students is already an innovative teaching. [...] it's not just innovative to say we all use our iPad.

Ms. H. understood innovation to be manifested in small changes that are not always noticeable. Ms. H. felt innovation didn't have to be new media (e.g. the use of an iPad), but also included lessons that are adapted to the abilities and interests of the students. Teachers are very interested in student opinions on innovation, and a culture of feedback, therefore, plays an important role in class as well as in the collegium. When students are involved in decisions about new approaches in class teachers saw a higher level of motivation. Mr. F. (personal communication, December 13, 2017) said the following:

And there are certainly methods where I say: Yes, well, it was nice to try that out now, but it wasn't so productive for me now [...] for me it is important what comes out at the end of the lesson. [...]. You ask the students because you are also interested in it: "Have you done this before?", and then sometimes the answer is: "Yes, we already know it in general". Then that is good. Then they already know the method at least once and some things are then also new for the students in this form.

In this example, personal subjective perception and assessment of the execution of innovation are crucial. Mr. F. pointed out that innovations should provide links to 
known elements to ensure greater acceptance. In this context, the learning success of the students was important to him. He felt open to new methods but the personal benefit, in terms of the outcome of the innovation, is a deciding factor for the adaptation of such methods. According to this, not every novelty is an innovation for the interviewees, but only when it has been positively evaluated. This assessment should not only be made against the background of the necessary workload but should also include the learning outcomes of the pupils. Teachers believed that innovation that builds on what the students already know is particularly effective. This is followed by Ms. O.'s perception (personal communication, November 13, 2017): "I think that for me, innovation is something that has its hands and feet, i.e. where there really is a red thread."

It was important to teachers that innovation had structure and clear objectives, which is very different from actual innovation processes beyond the educational realm. They assessed their goals using the learning goals of the lesson, and thus in connection to the learning growth of the students. The controversial aspect of this understanding is that compared to Mr. F. and Ms. O., Mr. W. evaluated the success of innovation through the fun that the students had and not through the learning success. This shows that there are problems with the determination of success due to innovation.

For Ms. H. (personal communication, November 2, 2017), innovation is a basic prerequisite for professional teaching and personal development:

I don't think it will work without innovation. So, I think the teacher who doesn't allow any innovations in his teaching [...] may no longer have his profession in focus but just works for himself. For me, innovation is one of the most important points in class.

Ms. H. emphasized that for her innovations are an integral part of the professional behavior of teachers who seek good learning outcomes for students, but it has to do with workload. This makes it clear that dealing with innovations is associated with work and time consuming, which could have a negative impact on some teachers.

There was also innovation that was assessed negatively, which tie in with the curricular understanding (innovations from outside) already presented: "[...] in geography there are always movements towards some curricular changes that are simply borderline. This is an innovation in $[\ldots]$ geography and $[\ldots]$ these things come in from the outside" (Mr. R., personal communication, November 3, 2017). In Mr. R.'s remarks, his rejection of some curricular changes is clear. He referred to a change in relation to A-levels tasks which he personally cannot influence. This opinion shows that if personal freedom of action is perceived as restricted (e.g. by educational or structural changes from outside the area of influence), behavior towards changes stagnate and are rejected by teachers. Acceptance of innovation depends on the gap (in terms of the idea of the innovation) between the origins of the innovation to the teachers. According to Mr. R., an innovation intended for school and teaching have to be developed and implemented by teachers and students: "[...] I think innovation from inside the teacher staff [...] is what represents an innovation. Once innovation comes from the outside, it's more of a problem because they don't know how the school microcosm works [...]" (personal communication, November 3, 2017). Thus, for Mr. R. innovations that originate from 
the nearest environment (i.e. geography teacher colleagues) are understood as innovations as such and are mainly considered to be positive.

However, not all teachers agreed: Mr. F. stated that there would be no major changes without changing the curricula: "[...] if the core curricula do not change seriously, then the classroom does not change [...]" (personal communication, December 13, 2017). According to his perception, there must be external influences otherwise no changes will be undertaken. Therefore, it could be concluded that teachers derive the quality of innovation from their personal convictions and involvement. They assess innovation with the question to what extent an innovation brings advantages in their own teaching. In their assessment of innovation, they are guided by their subjective theories and reveal differentiated patterns of understanding. It was found that geography teachers understood innovation as novelties that bring advantages. If innovation does not show positive effects, then it is not understood as innovation. These positive effects can be positive feedback from students and colleagues or the personal feeling of success and the learning success of the students. However, the extent to which innovation enriched personal teaching and brought personal advantages differs from teacher to teacher. Through feedback from students and colleagues, teachers are encouraged to adopt innovations. Only if the class or the collegium accepts the innovation it is regarded as innovation by the interviewees. There is disagreement about innovations that come into the classroom from outside the teachers' sphere of influence. On the one hand, some assessed such outside innovation negatively because they cannot decide whether or not to accept such a change. On the other hand, other teachers saw lasting changes in teaching through top-down innovations.

\section{Realization of Innovation}

The following section describes the factors that the interviewees outlined for the implementation of innovation. Moreover, individual routines as well as innovative methods, media and topics are presented from the teachers' perspective.

Break with routines. For the interviewees, a routine was a prerequisite for innovation. The description of a typical geography lesson by the interviewed teachers was very similar for the majority of the interviewees. Each of the teachers described phases in teaching according to introduction, development, and saving, as well as using similar technical terms in the German geographic education literature such as 'Einstieg', 'Erarbeitung' and 'Sicherung'. In the introduction phase, the problem and the subject of the lesson were developed and presented. In the development phase students work on the subject to clear the problem and in the saving phase, the result is presented and practiced. Mr. B. gave an example of this (Mr. B., personal communication, March 9, 2018):

The typical process begins with [...], I make an initial impulse. This can either be given by an image or a question. [...]. Media are used, because we have the possibility to work with pictures, panels, whatever, especially in geography. [...] Then it continues in such a way that it goes into the development phase [...] and we come to the saving and we can stop then mostly either by the presentation [...]. 
All interviewees with this routine perceived it as very useful and rated the described course of lessons positively. The reason for the agreement in the process of teacher education is considered to be due to this method being taught and practiced throughout Germany and so these are typical teaching phases (introduction, development, saving). Additionally, another positive routine processes were identified. For example, the media used in the introduction phase: "I start with a picture or a video for the introduction typically" (Mr. W., personal communication, March 1, 2018).

For Mr. W., it is routine to start his lessons with pictures or videos, which he uses to introduce the question of the lesson. For some teachers, the more routine and security there is in teaching, the more flexible and open they can be to change and therefore to innovation. Mr. W. reaffirmed this in his statement (Mr. W., personal communication, March 1, 2018):

[...] the routine you get. So that many things are automatized and all this pedagogical, which still runs alongside, turns into automatisms. And that also takes a lot of work away during your lesson. You can then concentrate more on the lessons.

In Mr. W.'s perception routine enable professional action and give room and freedom for reflection on the lessons themselves. If general pedagogical activities, such as counseling situations or dispute resolution in class, are automated, the actual teaching of content and methods are easier to achieve. For Mr. W. routine is generally regarded as helpful in the pedagogical field (e.g. routine in counseling situations) and in the regular course of lessons (phases in class).

Some teachers saw breaks in routine as an important part of introducing innovation. Mr. P. described this in relation to the use of the textbook:

[...] standard lessons are just so with the book [...] that's exactly what it is to the students $[\ldots]$ and then when the digital projector turns on and there comes a short video and it is only 30 seconds long. If the 30 seconds are good, they're happy (personal communication, February 21, 2018).

He regarded the routine of using the textbook as an obstacle to the implementation of innovation. The independence from textbooks and access to content via alternative media, such as the use of the digital projector, is innovative in his perception. Innovation must be something new that is unknown or unexpected to the students. Ms. H. realized that there can be no innovation at all without a routine in her own teaching since other commitments are so time-consuming and her own teaching consequently suffers as a result:

A teacher is always at work on 5000 tasks at the same time. But the actual core business, the teaching, is sometimes not the actual focus, and I think that's a shame. I hope that this development will make this part of my life even easier, so that I can make this even more routinely and that will come with time (personal communication, November 13, 2017). 
Ms. H. had only recently entered the teaching profession and therefore had not yet the time to establish a routine, but in her perception routine is necessary and seen as something positive.

Young teachers saw a change in school or entry into the teaching profession as the trigger for innovation. An existing routine was also seen as a potential for innovation with a change of student environment. Some of the teachers interviewed were motivated to initiate changes. These interviewees enjoyed teaching and wanted to learn something new. Another motivational factor that was cited was feedback from students. If new approaches were followed by positive feedback from students some teachers are motivated to try out further innovation. Routines were seen as a prerequisite for innovation because some teachers lack the time for a change of perspective and an external view of their own teaching without them. Most teachers rated routines positively and were satisfied with their personal routines. The teachers interviewed considered work relief and time-savings in routines. However, routines were found to be long-term hindrances to innovations; some teachers were convinced that some routines work and do not consider breaking with them, although there is potential for innovation within them.

New methods. The teachers were asked about innovative methods in their geography lessons. Teachers understood innovative methods as methods based on their knowledge of current scientific knowledge, whether from sources such as scientific articles or education literature. For example, methods based on the Thinking Through Geography principle (Leat, 1999) are regarded as innovative: "I do this TTG" (Mr. W., personal communication, March 1, 2018).

Furthermore, we noticed that teachers not only considered geography education methods but also general education methods as innovative methods for their geography lessons, like in the case of Mr. F.: "Kind of a learning pace duet (Lerntempo-Duett)" (personal communication, December 13, 2017).

Ms. O. sees the parents in a supporting function to methodical innovation and therefore strives for more cooperation with them:

And what I also think is very important is to mobilize parents. There is parenthood in a wide variety of professions. And there are also often somehow geographic touches that I can use in class. And when they have brought someone into the class who reports something [...] first of all it is interesting for students [...] it is a good thing methodically and it helps a little bit (personal communication, November 13, 2017).

Ms. O. sees the potential of parents to help implement methodical innovation (e.g. in the form of expert surveys or expert lectures). In her example, Ms. O. wants to mobilize parents (external 'experts') to combine geographical topics with their professions so that the students get to know a different perspective to that of their teacher.

New media. The progressive digitalization and addition of technical equipment in schools are considered to be a reason for changes in teaching and are therefore perceived as innovation. Above all, they associate this with the emergence of 
digitization as an innovation generally: "[...] based on my understanding of innovation. I'm sure something's changed. It is going in the right direction in many areas. But it could certainly still be optimized, like the digitization of the school" (Mr. F., personal communication, December 13, 2017).

According to Mr. F., digitization is not yet sufficiently advanced in schools and sees a need for innovation in this field. However, technical devices such as the digital whiteboard are considered innovative: "Such a whiteboard is a nice thing and that is definitely something that has changed [...]" (Mr. F., personal communication, December 13, 2017).

Mr. F. rated the use of digital whiteboards very positively. He identified the advantages of these devices, for example in working with digital maps. With the aid of digital media, he sees advantages in the visualization that cannot be achieved otherwise. Furthermore, it is a personal concern for Mr. R. to transport digital media to school, as he also saw the need for innovation here:

[...] that we are appropriately equipped with digital media. But that would be personal to me, a huge incentive that I try to bring into school every day. PC's, networking, internet and so on. There are so many great programs and GIS systems $[\ldots]$ that are things you wouldn't get that way (personal communication, November 3, 2017).

But at the same time, Mr. F. explained that whilst digital media and technical innovations bring many advantages, analog media should not be neglected.

[...] the digital component is added, of course. I think that this has many advantages, but I also think that we must not completely neglect everything else. That's why I still work with foils and posters in the same way. But, of course, the students also do a lot of presentations digitally these days. So, this is definitely a change in class (Mr. F., personal communication, December 13, 2017).

The interplay between innovation and routine can be seen in responses such as Mr. F.'s, showing that, despite the positive evaluation of medial innovations, routine such as working with analog media are not neglected, and that it is, in fact, beneficial to integrate old and proven media in the classroom, in addition to innovative media. Teachers that see the advantages of medial innovation refer this to the proximity to the students' environment. Their perception is that digital media is more accepted by students than analog because of the increasing influence of digital media on their everyday lives. Nevertheless, digitization is not seen as the ideal innovation by everyone: according to Ms. O.: "[...] they are trying by force us to process it all digitally and so on" (personal communication, November 13, 2017).

Teachers that behave in a negative way towards digital media often have minimal personal interaction with technology and therefore find it difficult to adapt to digital media. In their understanding, the increased focus of geography lessons on digitization is one-sided and potentially innovative analog media developments are subsequently sidelined. Moreover, Ms. O. sees the change to digitalization in the school environment 
as an external force (curricular change) that is dictating how teachers should educate students.

New topics. In terms of innovative content, some teachers see how topical an issue in the news or print media as a decisive factor in whether they include it in their teaching.

I already think that the sustainability topic is relatively well covered in lessons. [...] I think innovation is simply missing here. I think that's just all the things you hear on the news that are up-to-date and sustainability is [...] not so topical anymore. And I think other issues such as energy or geopolitics, wars for resources, that sort of thing are the interesting topics you can do in class (Mr. W., personal communication, March 1, 2018).

For Mr. W., covering innovative topics in his lessons is important. He considers current events that are discussed in the news to be innovative, and not the sustainability issue, that is thematized in school. Some teachers see a conflict between the topicality of geographical content and the curriculum. Current topics, such as global problems and crisis situations, generally take up too little space in class because the curriculum is too narrow:

The current worldwide refugee crisis. [...] Covering this issue might just bring it a little bit more into the students' consciousness and maybe also find approaches to address it in geography lessons. The oil and drinking water problems are, of course, something we already know, but most of the time you don't dive so deep into them (Mr. F., personal communication, December 13, 2017).

Most interviewed teachers want more physical geography in schools (the current curriculum of NRW contains almost no physical geography) and this is where they see the potential for innovation, especially in the upper school where the focus is on human geography. Those who had a personal focus on physical geography in their studies and further education would also like to apply what they have learned in their own education.

It was evident throughout the interviews that innovative content plays a secondary role in teaching for teachers. Most of the teachers interviewed are not aware of current research and innovative topics are less relevant and even current discourses within the geographic and geography education discipline are only briefly considered.

\section{Obstacles to Innovative Teaching}

There was a broad consensus among teachers of the obstacles for innovation. First and foremost, school equipment was seen as important for technological advance. There is currently a shortage of technological tools and digital media in some schools, which is considered to inhibit innovation: "[...] then of course such a whiteboard is a nice thing and that is definitely something that has changed, because when I started in this school, we hadn't such a whiteboard at the very beginning" (Mr. F., personal communication, December 13, 2017). 
Mr. W. noted that innovation is important but its implementation in schools is marked by obstacles such as the school timetable or the curriculum:

I believe that the framework is so narrow that there is little room for maneuver. Be it purely practical due to external conditions such as that you may need more time or a different space for something innovative. Or simply the curriculum is too narrow. However, you have students who would like to be innovative. Everyone involved would like. But you are not allowed. And that's why I believe that innovation takes a relatively long time until it really arrives at a school. Take a look at what is considered to be new media in learning; that's Facebook right now, but none of them are using that. I think it's all too slow.

From Mr. W.'s statements, it is obvious that personal room for innovation is limited by the curricula. He also noted that even new school material being developed in relation to the curriculum is out of to date. Therefore, he thought that although innovations exist too much time passes between its development and the innovation arriving in the school, so that when it arrives, the innovation is no longer new. The most frequently mentioned innovation-inhibiting factor is the time required. From the shortened time up to spent by students at the school the overcrowded curriculum, to the time needed for research and preparation of new material. For example, previously mentioned constructivist methods provide teachers with an increased workload and they, therefore, fall back on classical methods due to a lack of time. Teachers, therefore, think that innovation cannot be implemented due to time and curricular constraints. However, small deviations from a teaching routine can create an opportunity for innovation, which does not have to be time-consuming, as individual teachers describe. For example, a short use of the digital projector alone can increase student motivation and is seen as innovative to them, as long as it is not used frequently. Even deviations without geographical or curricular reference are evaluated positively and are understood as innovation by students and teachers alike. Some teachers are generally open and motivated to innovate in this perspective and these teachers intend to use innovation but often do not implement it due to the aforementioned internal and external influences.

Another obstacle that some teachers mentioned is that of uncertainty with innovation: "I'd rather take the safe route" (Mr. W., personal communication, March 1, 2018). As there is often a lack of consensus on the meaning of innovation teachers do not know whether they are being innovative or not. It is therefore not easy for them to assess the success of the innovation as they cannot fully evaluate the learning outcome of the students after the innovation. However, teachers need to overcome their insecurity and try to incorporate innovation into their lessons, or they will close themselves off from the new and stick to their old routine. 


\section{Discussion}

The aim of this study was to answer what was teachers' understanding of innovation to determine what this understanding was dependent on and to what extent it influences the intention of geography teachers to be innovative in geography lessons. The majority of geography teachers interviewed had a methodical and curricular understanding of innovation in the sense of Schaub and Zenke (2007). Figure 2 shows the innovation matrix from the perspective of the teachers interviewed (in the style of figure 1).

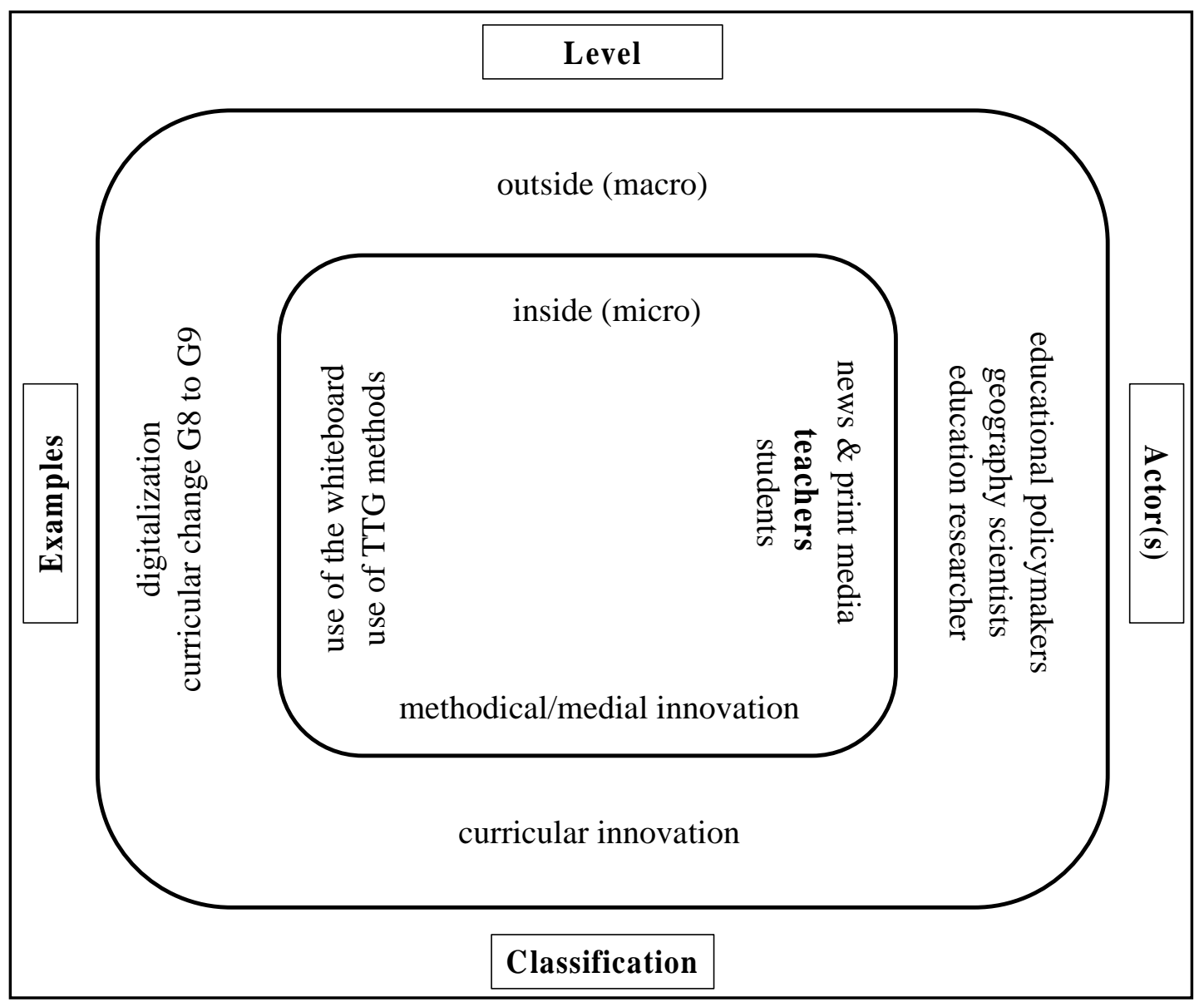

Figure 2. Innovation matrix displaying the perception of innovation by the interviewed teachers (own illustration).

Innovations in teachers' own geography lessons (micro level) were mainly understood as the use of new methods or media tools, such as the digital whiteboard. The teachers interviewed saw themselves as the main initiators of such innovation and call these innovations 'innovation from the inside'. This type of innovation is unanimously rated as very positive by all interviewees, as the selection and implementation of the innovation are left to the teachers. Therefore, the actors in this level of effect (Goldenbaum 2013) are teachers, and in some cases students, who participate in the creation, adoption, and implementation of innovation. Some of the interviewed teachers quoted different methods but these did not reflect the origin of these methods. These teachers were usually not aware of where the educational 
knowledge came from and related it mainly to themselves. Another 'actor' identified by the interviewees was the news and print media, which are seen as current sources of content for teaching.

Curricular innovation 'from outside' such as the curricular change from G8 to G9 are mainly considered negatively in comparison to 'innovation from the inside' and are equated with external control and interference in one's own actions. The interviewees considered the success of implementing innovation in a bottom-up procedure. The actors at this level are similar to the proposed actors in Figure 1, which include educational policymakers and researchers. Not all interviewed teacher shared this negative attitude towards curricular innovation; some stated they expected no innovation would occur without such top-down regulation. However, overall geography education and geography science were generally considered to be of little importance to such top-down innovation.

Generally, teachers showed little consideration of meso-level innovation, i.e. innovation of an institutional kind that can be influenced by both teachers and external parties. Consequently, institutional innovation seemed to be of little importance to the teachers interviewed, although this is the area in which the aversion to 'the outside' may be overcome.

Another noteworthy feature is that, unlike the matrix in Figure 1, the interviewed teachers did not identify a fluid boundary between individual types of innovation. For them, a huge contrast between "internal" innovations and "external" innovation remains. Conditions such as digital equipment or context in which the innovation is to be implemented are crucial. Furthermore, personal benefits that are associated with the innovation were often also referred to e.g. time-saving or fun. Thus, the emotions that teachers associated with innovation are considered to plan an important role. This point can be linked to the previous point in terms of the origin of an innovation. Teachers who see themselves as innovators must have a good feeling and receive positive feedback from students, and only then they do understand innovation as innovation, and consequently evaluate these changes positively. However, different understandings and emotions related to innovation lead to different assessments of the effectiveness of the implemented changes. Teachers who have a methodical focus in their understanding of innovation are more inclined to evaluate and implement them positively whilst teachers who have a mainly curricular understanding of innovation are more likely to reject the implemented changes. During the interviews, there was no reflection on failure with innovation and it seems that teachers take a defensive attitude towards unsuccessful attempts with innovation.

The most important condition for innovation, and at the same time aspect teachers were most ambivalent about, was routine. On the one hand, it was clear that innovation cannot occur without routine as the main criteria for innovation are breaking with routine. On the other hand, the teachers interviewed did not recognize routine as an obstacle to the implementation of innovation. Routine is particularly important to new teachers who have not yet developed any or few routines and therefore find it difficult to determine innovation for themselves as everything is new for them. In contrast, more 
experienced teachers found it difficult to change their routines because these routines have been proven to be very effective in their point of view. Generally, teachers consider routines to be advantageous for time-saving, reliability in teaching and work relief. However, in the long term, fixed routines are inhibiting innovation in the classroom. Some teachers were satisfied with what was going well and did not see the need for innovation so long as they felt teaching outcomes were good and the students were satisfied. However, some teachers recognized the problem with routine and those who had developed routines for themselves and subsequently reflected on their actions did not have a problem with breaking with them and being innovative.

A gap in scientific literature can now be recognized because the evaluation of routine in geography lessons lacks a theoretical framework and the importance of routine in connection with innovation. Most studies related to geography and innovation provide methodical and medial approaches and their implementation and impact in the classroom (Reinfried, 2009; Ditter, et al., 2011; Falk \& Faller, 2016;) but there is a need for developing an understanding of innovation competence (Gryl, 2013, Weis et al., 2017), where students should be prepared for the future and be able to act innovatively. But if teachers do not have a clear understanding of innovation they will not be able to teach it effectively. This study can be used as a basis for raising awareness of the concept of innovation for teachers, their assessment of innovation and critical reflection on their personal behavior.

\section{Conclusion}

This study has identified the understanding of innovation by geography teachers and their assessment patterns in connection with innovation. It was not intended to provide concrete proposals for innovation or for whom which innovation is useful, or what a real innovation is in geography teaching. We find this question very difficult, even impossible to answer because there is no universal definition of innovation in teaching. The definition proposed here reflects only a small part of the diversity of innovation in geographical education. Therefore, an innovation must always be seen in its respective context (e.g. level of effect, classification). This could open up a debate on what innovation means in geography education. Teachers seem to have difficulties talking about innovations, either through uncertainties on what a good or a bad innovation depends on, or due to a general skepticism towards external innovation (macro-/mesolevel). The "outside-inside problem" needs more exploration through research to determine how the gap between bottom-up and top-down innovation can be overcome. A connection with the attribution theory (Heider, 1977) could be considered as a starting point. The described gap in institutional understanding of geography teachers could be the starting point for interviews with geography teaching instructors. These would form a link between science and active teaching, so the understanding and assessment of innovation in geography and how teachers perceive current geography teaching can be understood in greater detail. 


\section{References}

Arnold, T. J., Fang, E. (Er), Palmatier, R. W. (2010). The effects of customer acquisition and retention orientations on a firm's radical and incremental innovation performance. Journal of the Academy of Marketing Science, 39(2), 234-251. https://link.springer.com/article/10.1007/s11747-010-0203-8.

Birkenhauer, J. (2010). Proposals for a Geography Curriculum '2000+' in Germany. International Research in Geographical and Environmental Education, 11, 272-277. https://doi.org/10.1080/10382040208667491.

Budke, A. (2015). Methoden der geographiedidaktischen Forschung. In A. Budke, \& M. Kuckuck (Eds.), Geographiedidaktische Forschungsmethoden (pp.1-37). Berlin-Münster: LIT Verlag.

Budke, A., \& Uhlenwinkel, Anke (2011). Argumentieren im Geographieunterricht Theoretische Grundlagen und unterrichtspraktische Umsetzungen. In C. Meyer, R. Henry, \& G. Stöber (Eds.), Geographische Bildung. Kompetenzen in der didaktischen Forschung und Schulpraxis (pp. 114-129). Braunschweig: Westermann.

Borko, H. (2004). Professional Development and Teacher Learning. Mapping the Terrain. Educational Researcher, 33(8), 3-15.

Bormann, I. (2013). Wissensbezogene Innovationsanalyse - ein Beitrag zur Erweiterung von Forschungstraditionen. In M. Rürup, \& M. Bormann (Eds.), Innovationen im Bildungswesen (pp. 90-109). Wiesbaden: Springer Fachmedien.

Böhn, D., \& Hamann, B., (2011). Approaches to sustainability. Examples from geography textbook analysis in Germany. European Journal of Geography, 2(1), 1-10.

Bullinger, H.-J. (1994). Einführung in das Technologie-Management. Stuttgart: Teubner.

Dann, H.-D. (1994): Pädagogisches Verstehen: Subjektive Theorien und erfolgreiches Handeln von Lehrkräften. In: K. Reusser, M. Reusser-Weyeneth (Eds.), Verstehen. Psychologischer Prozess und didaktische Aufgabe (pp. 163-182). Bern: Verlag Hans Huber (Psychologie-Forschung).

Dewar, R. D., \& Dutton J. E. (1986). The adoption of radical and incremental innovations: An empirical analysis. Management Science, 32(11), 1422-1433. https://doi.org/10.1287/mnsc.32.11.1422.

Ditter, R., Voss, K., \& Siegmund, A. (2011): Innovative geography lessons with remote sensing methods. In T. Jekel, A. Koller, K. Donert, \& Vogler, R. (Eds.), Learning with GI 2011 Implementing Digital Earth in Education (pp. 204-207). Berlin: Wichmann.

Döbert, H., Ackeren Van, I., Bos, W., Klemm, K., Klieme, E., Lehmann, R., \& Weiß, M. (2003). Vertiefender Vergleich der Schulsysteme ausgewählter PISA - Teilnehmerstaaten. Berlin: BMBF.

Ettlie, J. E., Brigdes, W. P., \& O'Keefe, R. D. (1984). Organization strategy and structural differences for radical versus incremental innovation. Management Science, 30(6), 682695. https://doi.org/10.1287/mnsc.30.6.682.

Falk, G. C., \& Faller, M. (2016). Das Geowindow. Ein innovatives Unterrichtsmedium. In K. H. Otto, (Ed.): Geographie und naturwissenschaftliche Bildung - Der Beitrag des Faches für Schule, Lernlabor und Hochschule (pp. 258-262). Münster: Monsenstein und Vannerdat.

Flick, U. (2011a): Qualitative Sozialforschung. Eine Einführung. Reinbek: Rowohlt 
Taschenbuch Verlag.

Flick, U. (2011b): Das Episodische Interview. In G. Oelerich, \& H.-U. Otto (Eds.), Empirische Forschung und soziale Arbeit (pp. 273-280). Wiesbaden: Springer VS Verlag.

Fullan, M., \& Pomfret, A. (1997). Research on curriculum and instruction implementation. Review of Education Research, 47(1), 335-397. https://doi.org/10.3102/00346543047002335.

Glaser, B., \& Strauss, A. (1967): The discovery of grounded theory. Strategies for qualitative research. Chicago: Aldine.

Glaser, B., \& Strauss, A. (1999). The discovery of grounded theory. Strategies for qualitative research. New York, NY: Taylor \& Francis Inc.

Goldenbaum, A. (2013): Implementation von Schulinnovationen. In M. Rürup, \& I. Bormann (Eds.), Innovationen im Bildungswesen. Analytische Zugänge und empirische Befunde (pp. 149-172). Wiesbaden: Springer.

Gräsel, C., \& Parchmann, I. (2004): Implementationsforschung - oder: der steinige Weg, Unterricht $\mathrm{zu}$ verändern. Unterrichtswissenschaft 32(3), 196- 214. https://www.pedocs.de/volltexte/2013/5813/pdf/UntWiss_2004_3_Graesel_Parchmann_I mplementationsforschung.pdf.

Gryl, I. (2013). Alles neu - innovativ durch Geographie- und GW-Unterricht? GW-Unterricht, $131,16-27$.

Heider, F. (1977). Psychologie der interpersonalen Beziehungen. Stuttgart: Klett.

Helmke, A. (2012): Unterrichtsqualität und Lehrerprofessionalität. Diagnose, Evaluation und Verbesserung des Unterrichts. Seelze: Klett, Kallmeyer.

Hermanns, H. (1992). Die Auswertung narrativer Interviews: ein Beispiel für qualitative Verfahren. In J. H. P. Hoffmeyer-Zlotnik (Ed.), Analyse verbaler Daten: über den Umgang mit qualitativen Daten (pp. 110-141). Opladen: Westdt. Verlag.

Hermanns, H. (1995). Narratives Interview. In U. Flick (Ed.), Handbuch qualitative Sozialforschung (pp.182-185). München: Beltz.

Höhnle, S., Michel, B., Glasze, G., \& Uphues, R. (2013). Digital geo-data traces - new challenges for geographic education. International Research in Geographical and Environmental Education, 22(2), 97-108.

Jahn, M., Viehrig, K., Fiene, C., \& Siegmund, A. (2015). Mit Concept Maps systemisches Denken von Schüler/innen bewerten. In A. Budke, \& M. Kuckuck (Eds.), Geographiedidaktische Forschungsmethoden, Praxis Neue Kulturgeographie (pp. 340367). Berlin, Münster, Wien, Zürich, London: Lit- Verlag.

Jeckel, T., \& Pichler, H. (2017). Vom GW-Unterrichten zum Unterrichten mit geographischen und ökonomischen Konzepten. $\mathrm{Zu}$ den neuen Basiskonzepten im österreichischen GWLehrplan AHS Sek II. GW-Unterricht, 147(3), 5-15.

Klein, K. J., \& Knight, A. P. (2005). Innovation implementation. Overcoming the challenge. Current Directions in Psychological Science, 14(5), 243-246.

Küsters, I. (2006). Narrative Interviews. Grundlagen und Anwendung. Wiesbaden: Springer VS.

Lambert, D. (2011): Reframing school geography: A capability approach. In G. Butt (Ed.), Geography, education and the future (pp. 127-140). London: Continuum 
Krohmer, M., Budke, A. (2018) / Understanding and assessment of innovation by geography....

Lambert, D., Solem, M., \& Tani, S. (2015): Achieving human potential through geography education: A capabilities approach to curriculum making in schools. Annals of the Association of American Geographers, 105, (4), pp. 723-735.

Lauer, A. (2006). Möglichkeiten und Grenzen von Innovationen im Lehrplan - evaluiert am Beispiel der Jahrgangsstufe 6 im Fach Mathematik (Doctoral dissertation). Retrieved from OPUS Bibliothek Universität Augsburg. (https://opus.bibliothek.uniaugsburg.de/opus4/frontdoor/deliver/index/docId/326/file/Promotion_Abgabe_020806.pd f).

Leat, D. (1999). Thinking through geography. Cambridge: Chris Kington Publishing.

Mandl, H., \& Huber, G. L. (1982): Subjektive Theorien von Lehrern. Tübingen: Deutsches Institut für Fernstudien.

Mayring, P. (2002). Einführung in die qualitative Sozialforschung. Eine Anleitung zu qualitativem Denken. Weinheim: Beltz.

Mayring, P. (2008): Qualitative Inhaltsanalyse. Grundlagen und Techniken. Weinheim: Beltz.

Radtke, F.-O. (2004). Der Eigensinn pädagogischer Professionalität jenseits von Innovationshoffnungen und Effizienzerwartungen. Übergangene Einsichten aus der Wissensverwendungsforschung für die Organisation der universitären Lehrerbildung. In B. Koch-Priewe, F.-U. Kolbe, \& J. Wildt (Eds.), Grundlagenforschung und mikrodidaktische Reformansätze zur Lehrerbildung (pp. 99-149). Bad Heilbrunn: Klinkhardt.

Reinfried, S. (2009): Das Modell der Didaktischen Rekonstruktion - eine innovative Methode zur fachwissenschaftlichen Erforschung und Entwicklung von Unterricht. Einleitung. In K. Reusser, \& I. Tanner (Eds.), Unterrichtsforschung und Unterrichtsentwicklung. Jahreskongress der SGBF und der SGL vom 29. Juni -1. Juli 2009 (282-284). Universität Zürich.

Reinmann-Rothmeier, G. (2003). Didaktische Innovation durch Blended Learning. Leitlinien anhand eines Beispiels aus der Hochschule. Bern: Huber.

Reinmann, G. (2005). Blended Learning in der Lehrerbildung. Grundlagen für die Konzeption innovativer Lernumgebungen. Lengerich: Pabst.

Rosenthal, G. (1987): "Wenn alles in Scherben fällt..." Von Leben und Sinnwelt der Kriegsgeneration. Opladen: Leske \& Budrich.

Fischer-Rosenthal, W., \& Rosenthal, G. (1997): Narrationsanalyse biographischer Selbstpräsentationen. In R. Hitzler, \& A. Honer (Eds.), Sozialwissenschaftliche Hermeneutik (pp. 133-164). Opladen: Leske \& Budrich (utb).

Rosenthal, G. (2005). Interpretative Sozialforschung. Eine Einführung. Weinheim, München: Juventa.

Rürup, M., \& Bormann, I. (2013). Innovation als Thema und Theoriebaustein der Educational Governance Forschung - Zur Einführung in den Herausgeberband. In M. Rürup, \& I. Bormann (Eds.), Innovationen im Bildungswesen. Analytische Zugänge und empirische Befunde (pp. 11-44). Wiesbaden: Springer.

Schaub, H., \& Zenke, K. G. (2007). Wörterbuch zur Pädagogik. Grundlegend erweiterte und aktualisierte Neuausgabe. München: dtv.

Schmid, M. R. (1999). Wissensmanagement für den Innovationsprozess. Ein empirisch 
fundierter Beitrag zur Gestaltung und Umsetzung des Wissensmanagement-Ansatzes im produktorientierten Ideenmanagement bei DaimlerChrysler (Doctoral dissertation). Retrieved from Universität Bielefeld. https://pub.uni-bielefeld.de/publication/2305155.

Schramm, E. (2007). Möglichkeiten und Grenzen von Innovationen durch Lehrpläne. Evaluation am Beispiel der sechsten Klasse im Fach Deutsch (Doctoral dissertation). Retrieved from OPUS Bibliothek Universität Augsburg. https://opus.bibliothek.uniaugsburg.de/opus4/frontdoor/deliver/index/docId/604/file/Schramm_Lehrplaene.pdf.

Schulze, U., Gryl, I., \& Kanwischer, D. (2015). Spatial citizenship education and digital geomedia: composing competences for teacher education and training. Journal of Geography in Higher Education, 39(3), S. $369-385$. http://dx.doi.org/10.1080/03098265.2015.1048506.

Schütze, F. (1983). Biographieforschung und narratives Interview. Neue Praxis, 13(3), 283-293.

Weis, S., Scharf, C., Greifzu, L., \& Gryl, I. (2017). Stimulation by simulating: Fostering innovativeness in education. 2017 IACB, 2017 ICE \& 2017 ICTE Proceedings, 386-1386-9. https://www.cluteinstitute.com/conference-proceedings/sh17proceedings.pdf.

Witzel, A. (1985): Das problemzentrierte Interview. In G. Jüttemann (Ed.), Qualitative Forschung in der Psychologie (227-255). Weinheim: Springer VS Verlag.

Zapf, W. (1989). Über soziale Innovationen. Soziale Welt, 40(1/2), 170-183.

\section{Biographical statement}

Maxim KROHMER is a Ph.D. student at the University of Cologne in Germany. His research is focused on, innovation in geography, teacher training and perceptual research. He is also interested in curriculum research in geography.

Alexandra BUDKE is a professor of geography education at the University of Cologne. Her research is focused on argumentation in geography, civic education, intercultural learning, problem-solving and more. 